\title{
Geochemical characterization of Lucaogou Formation and its correlation of tight oil accumulation in Jimsar Sag of Junggar Basin, Northwestern China
}

\author{
Jiangxiu $\mathrm{Qu}^{1,2} \cdot$ Xiujian Ding ${ }^{1,2,4} \cdot$ Ming Zha ${ }^{1,2} \cdot$ Hong Chen $^{3} \cdot$ Changhai Gao ${ }^{1,2} \cdot$ \\ Zimeng Wang ${ }^{1}$
}

Received: 19 December 2016/ Accepted: 22 February 2017/Published online: 9 March 2017

(C) The Author(s) 2017. This article is published with open access at Springerlink.com

\begin{abstract}
With the constant consumption of conventional oil and gas resources, unconventional oil and gas resources with great resource potential such as tight oil have gradually been valued and become the new exploration area. Jimsar Sag is the key tight oil exploration and development block in Junggar Basin of Northwestern China. Based on the data sets of geology, oil production test, logging, rock thin section, and geochemistry of Permian Lucaogou Formation (LCG), we studied the geochemical characteristics of hydrocarbon source rocks and their relation to the tight oil accumulation. Organic matter abundance of source rocks is high, the types of organic matter are mainly type I and type II, and the organic matter maturation is in the low mature stage to mature stage. Results of oil source correlation showed that the crude oil of sweet spots was mainly derived from the source rocks in the interior of the sweet spots. The LCG tight oil is mainly distributed in the plane where the source rocks have great thickness and the TOC is higher than $3.5 \%$. It shows that the source rocks have obvious controlling on the occurrence and accumulation of tight oil.
\end{abstract}

Xiujian Ding

dingxj129@foxmail.com

1 School of Geosciences in China University of Petroleum, Qingdao 266580, China

2 Laboratory for Marine Mineral Resources, Qingdao National Laboratory for Marine Science and Technology, Qingdao 266580, China

3 Research Institute of Petroleum Exploration and Development, Xinjiang Petroleum Administration Bureau, Karamay 841000, China

4 Present Address: No. 66, Changjiang West Road, Huangdao District, Qingdao 266580, China
Keywords Tight oil - Source rock · Lucaogou Formation · Jimsar Sag · Junggar Basin

\section{Introduction}

With the successful exploitation of Bakken oil (Williston Basin, North America; Miller et al. 2008) and Eagle Ford oil (South Texas) (Mullen 2010), tight oil has been a research focus in global petroleum geology (Johnstone 2007; Zou et al. 2013; Hill et al. 2007) and was considered the most practical unconventional replacement for oil and gas besides shale gas (USGS 2008; Cao et al. 2016a, b). China is abundant in tight oil resources, as a new round of national petroleum resources assessment jointly completed by Land and Resources and other ministries thinks that tight oil favorable exploration area in China is $(41 \sim 54) \times 10^{4} \mathrm{~km}^{2}$, and the amount of geological resources is up to $200 \times 10^{8} \mathrm{t}$, accounting for $2 / 5$ of the recoverable oil resources (Wang 2013; Zou et al. 2014; National Key Basic Research and Development Program (973 Program) 2014); thus, tight oil has become one of the most realistic unconventional oil exploration areas (Wang 2013; Jia et al. 2012; Cao et al. 2016a).

In recent years much progress has been made in tight oil exploration of the Permian Lucaogou (LCG) Formation, which is the primary exploratory stratum of tight oil reservoirs in the Jimsar Sag, Junggar Basin, Northwestern China. Jimsar Sag is located at the eastern uplift of Junggar Basin and covers an area of $1278 \mathrm{~km}^{2}$. The Lucaogou Formation in Jimsar Sag, which formed in the sedimentary environment of a lacustrine basin, is a set of mixed fine-grained deposits. Mudstones, siltstones, sandstones, and dolomites are the main rock types with the characteristics of fine grains, thin single layers, and frequently alternating lithology ( $\mathrm{Si}$ et al. 
2013; Li et al. 2014). Although the LCG Formation generally has low porosity and low permeability, the physical properties and oil-bearing probability in some intervals are relatively better. Tight oil is widely distributed in Jimsar Sag, in which commercial oil with high production has been obtained in multiple wells and has a great prospecting potential (Kuang et al. 2012, 2013a, b).

Currently, the study on geochemical characterization of LCG Formation and its correlation of tight oil accumulation in Jimsar Sag of Junggar Basin is still relatively weak. We have conducted a comprehensive investigation on the source rock of LCG Formation, to define the geochemical characterization of LCG Formation and its correlation of tight oil accumulation in the Jimsar Sag of Junggar Basin.

\section{Geological setting}

The Jimsar Sag is located in the eastern uplift of Junggar Basin, which is one of the most petroliferous basins with great proven oil reserves and undiscovered resources in the Northwestern China (Fig. 1). The Sag has a total area of $1278 \mathrm{~km}^{2}$ and is a faulted depression with faulting in the west, and it overlies the Middle Carboniferous folded basement in the east. The tectonic activity in the inside of the depression is relatively weak (Zhao et al. 1994; Zou et al. 2014), and body exploration site is gentle with $3^{\circ}-5^{\circ}$ structural dip. Recently, commercial tight oil flow has been obtained from many oil wells, and the sag has been the focus of tight oil exploration and development in China (Wang et al. 2015; Jiang et al. 2015; Cao et al. 2016b, 2017).
The sag includes sedimentary cover from Permian to Quaternary with Middle Carboniferous flexure as the basement. LCG is the main target layer for tight oil exploration, which is mainly deposited in lacustrine environment (Kuang et al. 2013a, b; Zhang et al. 2003; Peng et al. 2011). LCG can be further subdivided into the lower Lucaogou Member $\left(\mathrm{P}_{2} \mathrm{l}_{1}\right)$ and the upper Lucaogou Member $\left(\mathrm{P}_{2} \mathrm{l}_{2}\right)$ (Jiang et al. 2015). Tight oil is mainly distributed in the sweet spots of $\mathrm{P}_{2} \mathrm{l}_{1}$ and $\mathrm{P}_{2} \mathrm{l}_{2}$, which is shown in Fig. 2 .

\section{Materials and methods}

The source rock samples in the Lucaogou Formation were analyzed in this study. They were collected from Jimsar Sag in the Junggar Basin. One sample set consists of 300 mudstone samples from different sedimentary facies. This sample set is pulverized to 80 meshes in preparation for Rock-Eval pyrolysis, total organic carbon content (TOC). A Rock-Eval instrument is used to perform the pyrolysis analysis, which provides the parameters of $T_{\max }, S_{1}$, and $S_{2}$. The temperature was set as $300{ }^{\circ} \mathrm{C}$ for $3 \mathrm{~min}$ and then heating at $25^{\circ} \mathrm{C} / \mathrm{min}$ to $650{ }^{\circ} \mathrm{C}$ (Ding et al. 2015). $T_{\max }$ is the temperature which corresponds to the maximum generation rate of hydrocarbons from kerogen cracking. $S_{1}$ and $S_{2}$ represent the amount of hydrocarbon of free and generated hydrocarbons, respectively. The TOC of the source rocks is measured using a LECO CS-230 analyzer.

Twenty-nine mudstones are used for gas chromatography-mass spectrometry (GC-MS) analysis. In order to assess organic matter type and depositional condition more
Fig. 1 Map of tight oil exploration results of LCG Formation in the Jimsar Sag, Junggar Basin

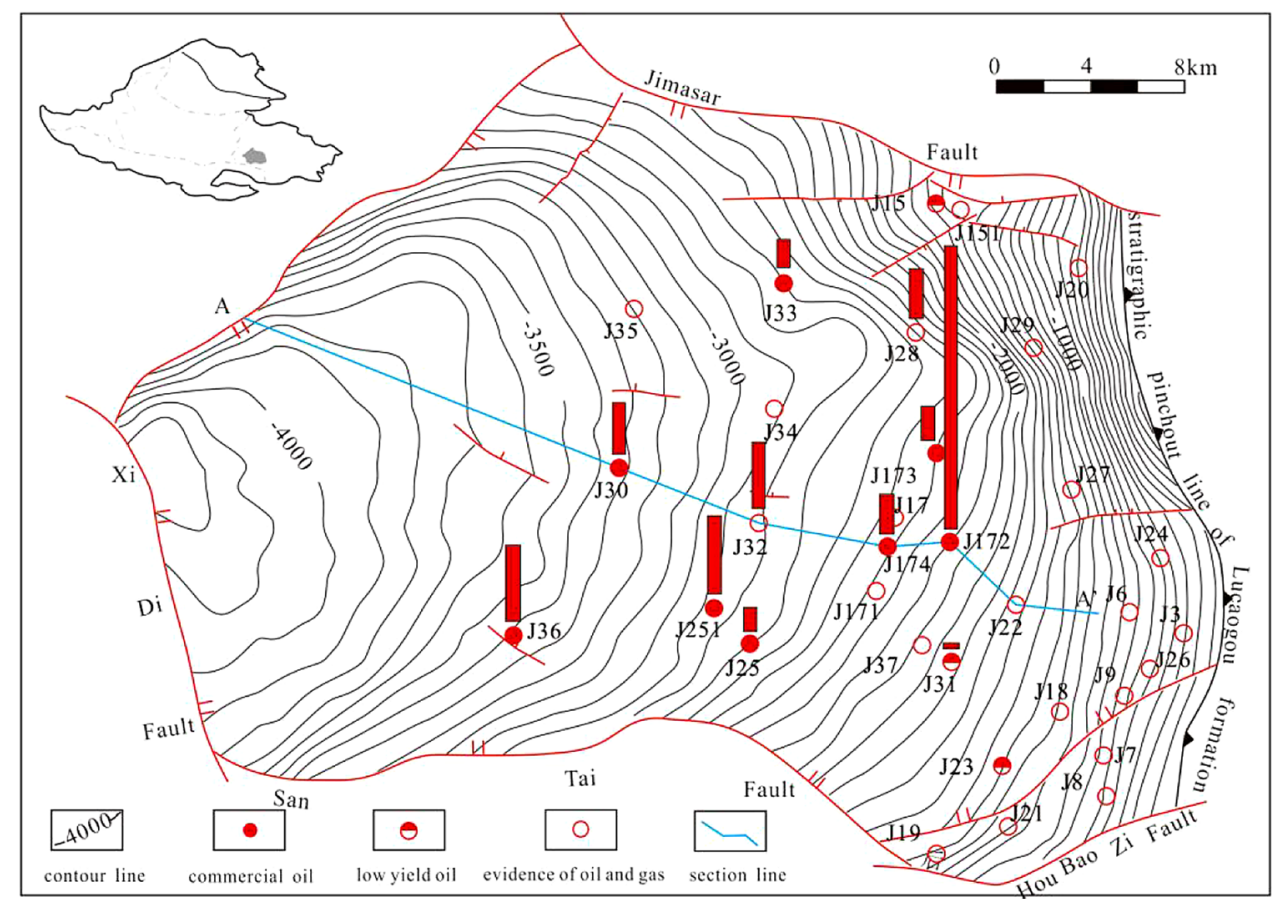


Fig. 2 Generalized stratigraphic column of LCG Formation in the Jimsar Sag, Junggar Basin

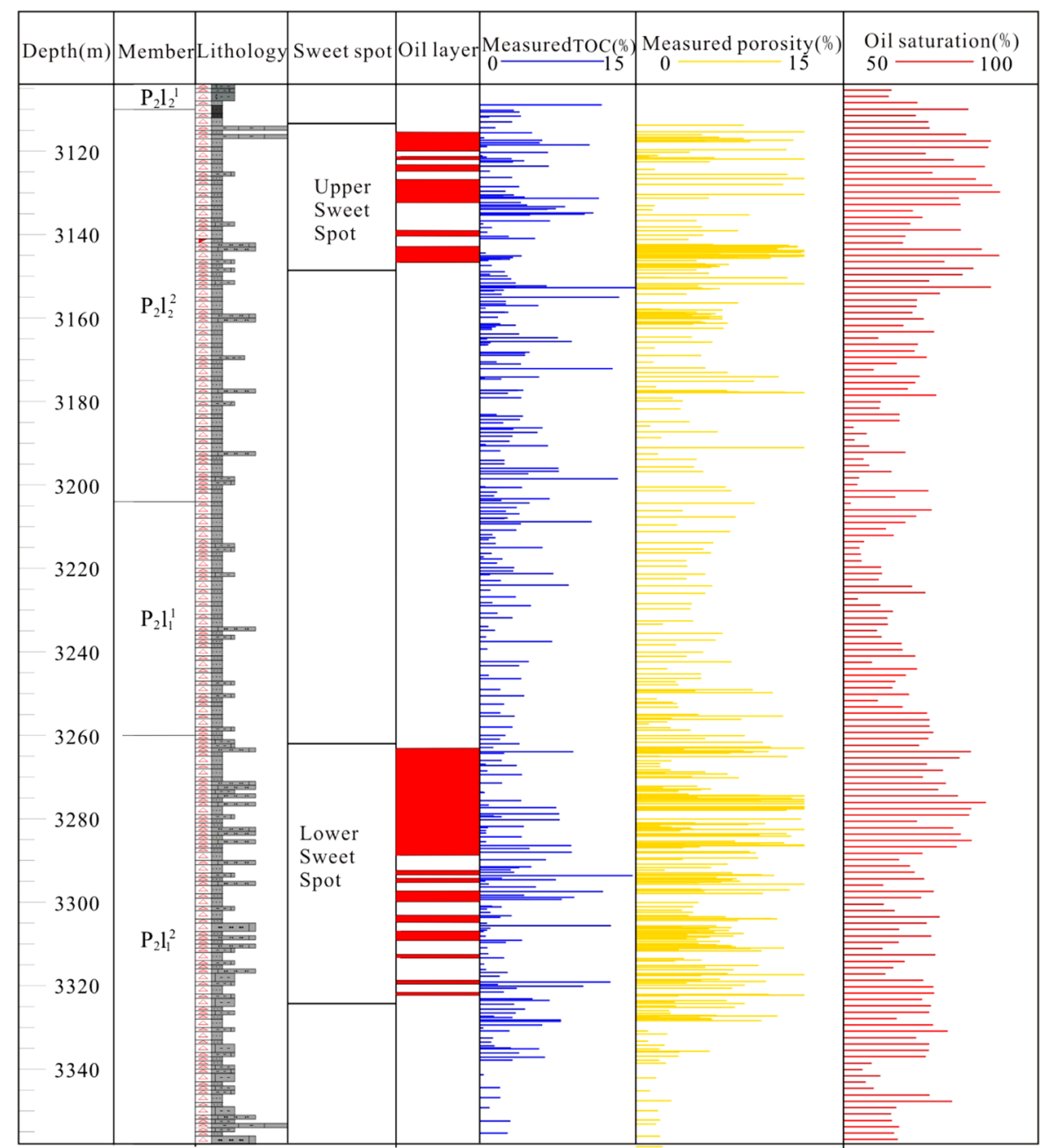

accurately, the limited mudstone samples are selected as dispersedly as possible from Jimsar Sag. The rock samples are cleaned prior to powdering. Soxhlet extraction was conducted using chloroform/methanol (87:13) for $72 \mathrm{~h}$, and the isolated extractable organic matter was separated into saturated hydrocarbons, aromatic hydrocarbons, and polars using column chromatography method. GC-mass spectrometry (GC-MS) analysis of the saturate fractions is performed with a HP6890GC/5973MSD instrument equipped with a HP-5MS fused silica column (30 $\mathrm{m} \times 0.25 \mathrm{~mm}$ i.d., film thickness $0.25 \mathrm{~mm})$. The G-Coven temperature for analysis of the saturate fractions is initially held at $50{ }^{\circ} \mathrm{C}$ for $2 \mathrm{~min}$, then programmed to $100{ }^{\circ} \mathrm{C}$ at $20{ }^{\circ} \mathrm{C} / \mathrm{min}$ and to $310{ }^{\circ} \mathrm{C}$ at $3{ }^{\circ} \mathrm{C} / \mathrm{min}$, and held at $310{ }^{\circ} \mathrm{C}$ for $16.5 \mathrm{~min}$. Biomarker ratios are calculated using peak areas of individual compounds. Carbon isotopic compositions of carbonate in the mudstone samples are determined by a traditional acid-release method. Powdered samples are treated with anhydrous $\mathrm{H}_{3} \mathrm{PO}_{4}$ at $25{ }^{\circ} \mathrm{C}$ for $24 \mathrm{~h}$ to liberate $\mathrm{CO}_{2}$, and the liberated $\mathrm{CO}_{2}$ is collected and sealed for carbon isotope analysis. The carbon isotopic ratio is analyzed on a Finnigan MAT 252 mass spectrometer. Results are reported in standard per mil d-notation relative to the V-PDB standard. The error of these analyses is less than $0.1 \%$. The results are listed in Table 1.

\section{Results}

\section{Organic matter abundance and Rock-Eval pyrolysis}

LCG source rocks exhibit a wide range in TOC contents, laterally from 0.53 to $12.42 \%$, and most of the TOC contents are less than 5\% (Table 1). Rock-Eval pyrolysis is a commonly used technique to assess hydrocarbon generating potentials and classify organic matter types (Peters 1986). The average value $S_{1}+S_{2}$ of source rock samples is $12.93 \mathrm{mg} / \mathrm{g}$, in the range of $4.96 \sim 176.65$, showing that the source rocks have high organic matter abundance (Table 1). The LCG Formation is high in organic matter 
Table 1 Geochemical parameter table of LCG Formation in the Jimsar Sag, Junggar Basin

\begin{tabular}{|c|c|c|c|c|c|c|c|c|c|c|}
\hline Depth (m) & $T_{\max }$ & TOC & $S_{1}$ & $S_{2}$ & $20 \mathrm{~S}(\%)$ & $\beta \beta(\%)$ & $\% \mathrm{C}_{27}$ & $\% \mathrm{C}_{28}$ & $\% \mathrm{C}_{29}$ & $\mathrm{Pr} / \mathrm{Ph}$ \\
\hline 3110.88 & 448 & 3.55 & 0.66 & 8.35 & 0.982 & 0.009 & 0.151 & 0.334 & 0.515 & 1.860 \\
\hline 3112.09 & 443 & 0.85 & 0.42 & 1.92 & 0.996 & 0.003 & 0.223 & 0.310 & 0.467 & 1.050 \\
\hline 3113.3 & 441 & 2.89 & 1.96 & 10.11 & 0.978 & 0.011 & 0.188 & 0.327 & 0.485 & 1.350 \\
\hline 3113.34 & 443 & 0.72 & 0.02 & 0.71 & 0.998 & 0.002 & 0.181 & 0.341 & 0.478 & 1.630 \\
\hline 3114.73 & 451 & 1.42 & 0.28 & 3.87 & 0.991 & 0.004 & 0.328 & 0.296 & 0.376 & 1.030 \\
\hline 3117.1 & 439 & 0.39 & 0.01 & 0.14 & 1.000 & 0.001 & 0.167 & 0.339 & 0.494 & 1.230 \\
\hline 3117.75 & 449 & 5.57 & 0.53 & 22.48 & 0.952 & 0.013 & 0.216 & 0.336 & 0.448 & 2.260 \\
\hline 3118.78 & 453 & 9.77 & 0.44 & 78.96 & 0.852 & 0.019 & 0.187 & 0.342 & 0.472 & 1.240 \\
\hline 3119.23 & 442 & 0.65 & 0.02 & 1.39 & 0.997 & 0.002 & 0.167 & 0.334 & 0.499 & 2.110 \\
\hline 3121.38 & 444 & 0.27 & 0.03 & 0.5 & 0.999 & 0.001 & 0.148 & 0.346 & 0.506 & 0.970 \\
\hline 3122.14 & 448 & 2.84 & 0.49 & 8.85 & 0.981 & 0.007 & 0.146 & 0.315 & 0.539 & 1.440 \\
\hline 3122.58 & 450 & 3.96 & 0.33 & 17.32 & 0.963 & 0.009 & 0.118 & 0.402 & 0.480 & 1.750 \\
\hline 3125.08 & 443 & 0.92 & 0.01 & 1.32 & 0.997 & 0.002 & 0.152 & 0.352 & 0.496 & 1.220 \\
\hline 3130.76 & 445 & 3.03 & 0.4 & 4.16 & 0.991 & 0.008 & 0.271 & 0.311 & 0.418 & 1.330 \\
\hline 3134.05 & 444 & 6.77 & 0.74 & 32.75 & 0.931 & 0.016 & 0.230 & 0.330 & 0.440 & 1.260 \\
\hline 3134.21 & 448 & 6.05 & 0.88 & 22.19 & 0.953 & 0.015 & 0.224 & 0.314 & 0.462 & 1.100 \\
\hline 3137.01 & 452 & 6.25 & 0.36 & 32.9 & 0.932 & 0.013 & 0.212 & 0.367 & 0.421 & 1.210 \\
\hline 3139.7 & 444 & 0.72 & 0.03 & 2.12 & 0.995 & 0.002 & 0.145 & 0.353 & 0.502 & 0.970 \\
\hline 3140.74 & 450 & 2.58 & 0.34 & 6.89 & 0.985 & 0.006 & 0.138 & 0.364 & 0.498 & 1.110 \\
\hline 3144.66 & 442 & 0.55 & 0.06 & 0.99 & 0.998 & 0.001 & 0.143 & 0.360 & 0.496 & 1.030 \\
\hline 3150.2 & 448 & 2.48 & 0.64 & 3.2 & 0.993 & 0.007 & 0.235 & 0.407 & 0.357 & 0.840 \\
\hline 3152.82 & 451 & 3.17 & 0.02 & 20.2 & 0.957 & 0.007 & 0.139 & 0.587 & 0.274 & 1.600 \\
\hline 3153.65 & 453 & 2.14 & 0.12 & 1.2 & 0.997 & 0.005 & 0.173 & 0.477 & 0.349 & 2.970 \\
\hline 3155.32 & 452 & 12.42 & 0.65 & 176 & 0.720 & 0.020 & 0.138 & 0.607 & 0.255 & 0.970 \\
\hline 3156.94 & 453 & 2.32 & 0.15 & 4.32 & 0.991 & 0.005 & 0.124 & 0.382 & 0.494 & 1.440 \\
\hline 3158.88 & 444 & 2.54 & 0.24 & 12.95 & 0.972 & 0.006 & 0.194 & 0.417 & 0.389 & 0.910 \\
\hline 3161.75 & 448 & 1.85 & 0.02 & 10.85 & 0.976 & 0.004 & 0.201 & 0.450 & 0.349 & 0.740 \\
\hline 3162.02 & 453 & 3.22 & 0.17 & 10.76 & 0.977 & 0.007 & 0.184 & 0.438 & 0.378 & 0.810 \\
\hline 3162.62 & 448 & 1.08 & 0.15 & 0.81 & 0.998 & 0.003 & 0.207 & 0.294 & 0.499 & 0.930 \\
\hline
\end{tabular}

$S_{1}(m g / g)$ the amount of hydrocarbon of free, $S_{2}(m g / g)$ the amount of generated hydrocarbons; $\% 27=\mathrm{C}_{27}$ steranes $/\left(\mathrm{C}_{27}\right.$ steranes $+\mathrm{C}_{28}$ steranes $+\mathrm{C}_{29}$ steranes $) ; \% 28=\mathrm{C}_{28}$ steranes $/\left(\mathrm{C}_{27}\right.$ steranes $+\mathrm{C}_{28}$ steranes $+\mathrm{C}_{29}$ steranes $) ; \% 29=\mathrm{C}_{29}$ steranes $/\left(\mathrm{C}_{27}\right.$ steranes $+\mathrm{C}_{28} \quad$ steranes $+\mathrm{C}_{29}$ steranes); $20 \mathrm{~S}(\%)=\mathrm{C}_{29}$ sterane $\alpha \alpha \alpha 20 \mathrm{~S} /(20 \mathrm{~S}+20 \mathrm{R}) ; \beta \beta(\%)=\mathrm{C}_{29}$ sterane $\alpha \beta \beta /(\alpha \beta \beta+\alpha \alpha \alpha)$

abundance, and it belongs to good source rock with fairly high hydrocarbon generation conditions (Fig. 3).

\section{Organic matter types}

The hydrocarbon potential of source rocks is not just about the hydrocarbon source rock organic matter abundance, but also the type of organic matter in the source rocks. Cross-plots of $T_{\max }$ versus HI $\left(S_{2} / \mathrm{TOC}\right)$ show that LCG source rocks are dominated by type I and II kerogen (Fig. 4).

\section{Organic matter maturity}

Most of source rock samples have Rock-Eval $T_{\max }$ of 435-455 ${ }^{\circ} \mathrm{C}$, suggesting a low maturity to maturity stage
(Table 1). The biomarker maturity parameters $\alpha \alpha \alpha 20 \mathrm{~S} /$ $(20 \mathrm{~S}+20 \mathrm{R}) \mathrm{C}_{29}$ sterane and $\beta \beta /(\alpha \alpha+\beta \beta) \mathrm{C}_{29}$ sterane parameters indicate that LCG source rocks are mostly in the low maturity to mature evolution stage (Fig. 5).

\section{Oil source correlation}

Biomarkers have drawn much attention in the past few decades, mainly because of their usefulness in assessing organic matter type and quality, depositional conditions (e.g., salinity, oxicity, anoxicity), thermal maturity level, biodegradation extent and lithology (Arfaoui et al. 2007; Ding et al. 2016). In the upper sweet spot, the source rocks in the interior of the sweet spot are characterized by high value of $\mathrm{Pr} / \mathrm{Ph}(>1)$, low $\mathrm{C}_{27}$ steranes, moderate $\mathrm{C}_{28}$ steranes, and high $\mathrm{C}_{29}$ steranes, which are consistent with the 


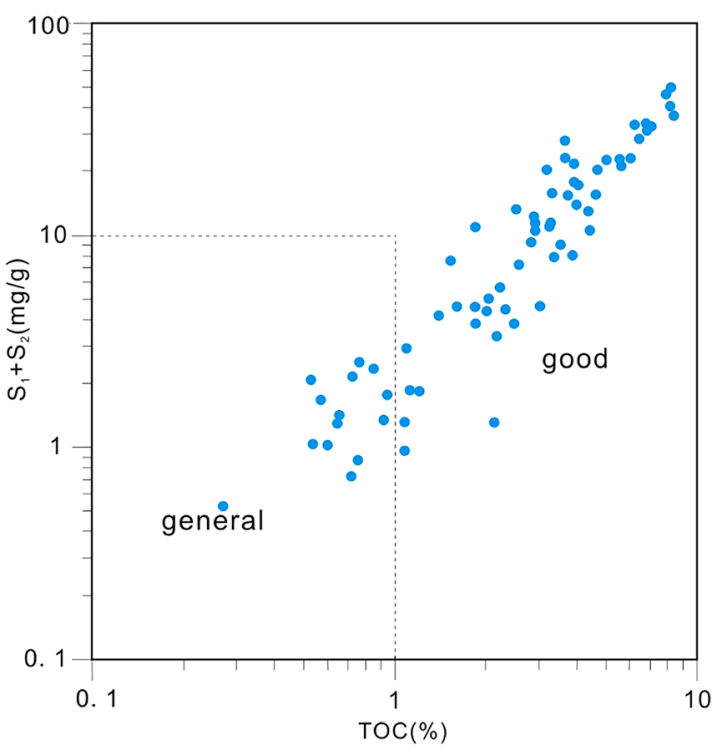

Fig. 3 Cross-plot of the total organic matter content (TOC) versus $S_{1}+S_{2}$, showing the high organic matter ambulance of LCG source rock in the Jimsar Sag of Junggar Basin

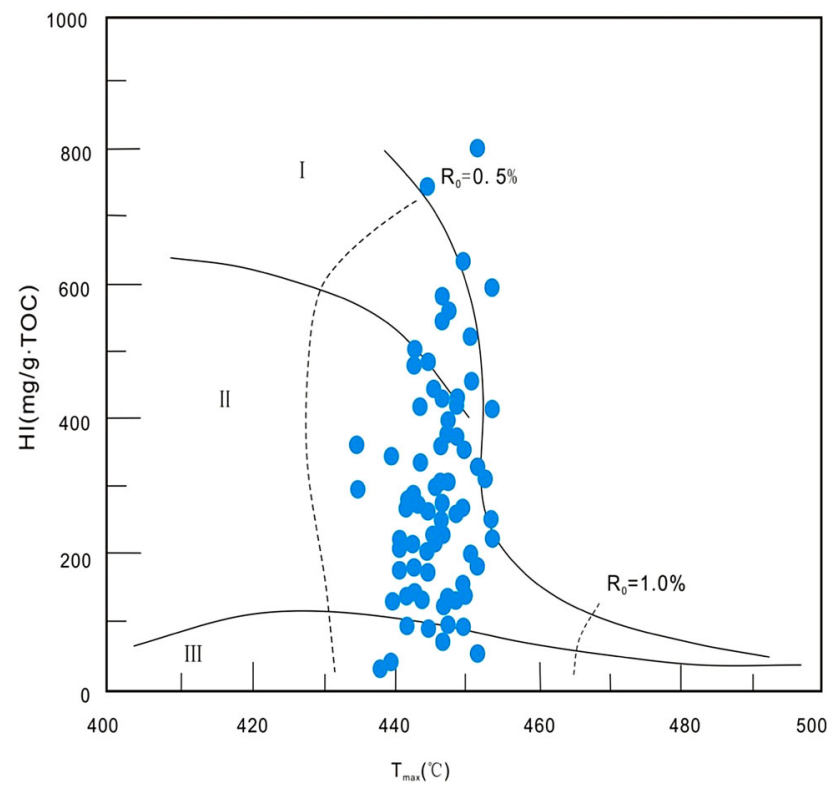

Fig. 4 Cross-plot of $T_{\max }$ versus HI ( $\left.S_{2} / \mathrm{TOC}\right)$, showing the organic matter type of LCG source rock in the Jimsar Sag of Junggar Basin

biomarkers characteristics of oil in the upper sweet spot (Fig. 6). And the source rocks under the upper sweet spot display low value of $\mathrm{Pr} / \mathrm{Ph}(<1)$, low $\mathrm{C}_{27}$ steranes, high $\mathrm{C}_{28}$ steranes, and moderate $\mathrm{C}_{29}$ steranes (Fig. 6).

In the lower sweet spot, the source rocks in the interior of the sweet spot are characterized by high value of $\mathrm{Pr} / \mathrm{Ph}$ ( $>0.8$ ), low $\mathrm{C}_{27}$ steranes, moderate $\mathrm{C}_{28}$ steranes, and high $\mathrm{C}_{29}$ steranes, which is consistent with the biomarker characteristics of oil in the lower sweet spot. And the

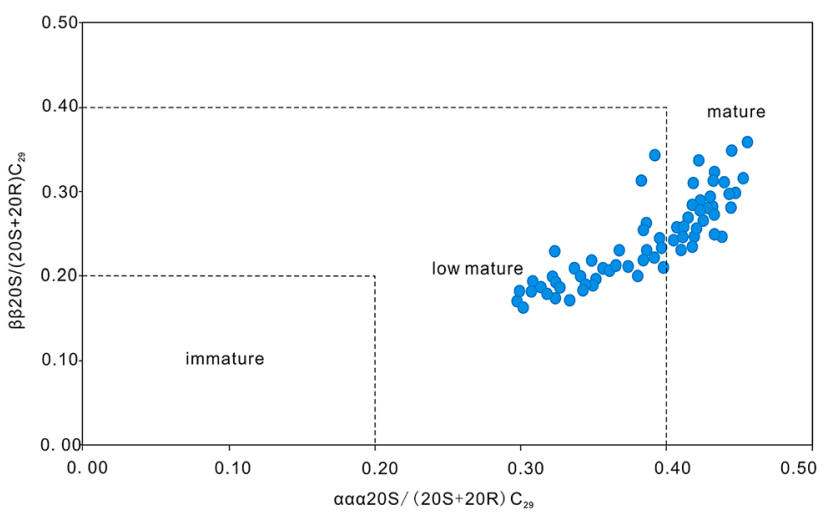

Fig. 5 Characteristics of the maturity parameter of soluble organic matter $\mathrm{C}_{29}$ regular sterane of Lucaogou Formation in Jimsar Sag

source rocks under the lower sweet spot display high value of $\mathrm{Pr} / \mathrm{Ph}(>0.8)$, low $\mathrm{C}_{27}$ steranes, high $\mathrm{C}_{28}$ steranes, and moderate $\mathrm{C}_{29}$ steranes. The analysis of the biomarker distribution indicates that the tight oil migration is dominated by primary or short-distance migration (Fig. 7).

\section{Discussion}

LCG tight oil is mainly distributed in the upper and lower sweet spot, where in upper sweet spot source rocks TOC is mainly distributed in the range of $2-8 \%$, lower sweet spot source rocks TOC is mainly distributed in the range of $0.5-6 \%$, and non-sweet spot hydrocarbon source rocks TOC is mainly distributed in the $0.5-4 \%$. Hydrocarbon source rocks abundance is significantly lower than the sweet spot, indicating that Lucaogou Formation tight oil is mainly distributed in the high organic abundance of source rocks symbiotic tight reservoirs, and high quality mature hydrocarbon source rocks inside or adjacent to tight reservoir is mainly tight oil distributed layer system.

The LCG tight oil accumulation is controlled by source rock and proved by that tight oil is mainly distributed in the region with thick source rocks and high abundance of organic matter. LCG Formation tight oil is mainly distributed in the region with hydrocarbon source rock accumulated thickness of more than $200 \mathrm{~m}$ region, where many commercial oil flow wells are located, such as $\mathrm{J} 174$ well and $\mathrm{J} 251$ well (Fig. 8a). And there are many evidence oil and gas wells in the region with source rock thickness of less than $200 \mathrm{~m}$, such as $\mathrm{J} 27$ well, J 29 well and J 35 well. The organic matter abundance also has significant control on tight oil distribution which is mainly distributed in the area of source rocks with TOC higher than 3.5\% (Fig. 8b). 
Fig. 6 Crude oil and the source rock geochemical characteristics of upper sweet spot in LCG Formation

Fig. 7 Crude oil and the source rock geochemical characteristics of lower sweet spot in LCG Formation oil sand
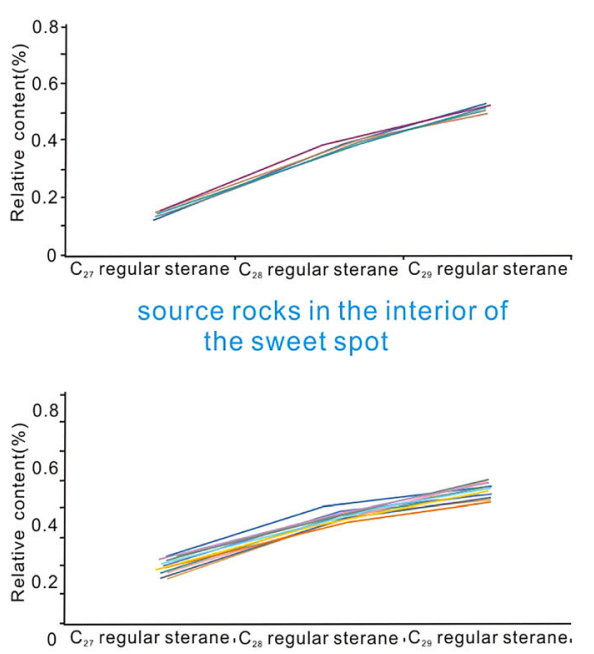

source rocks under the sweet spot
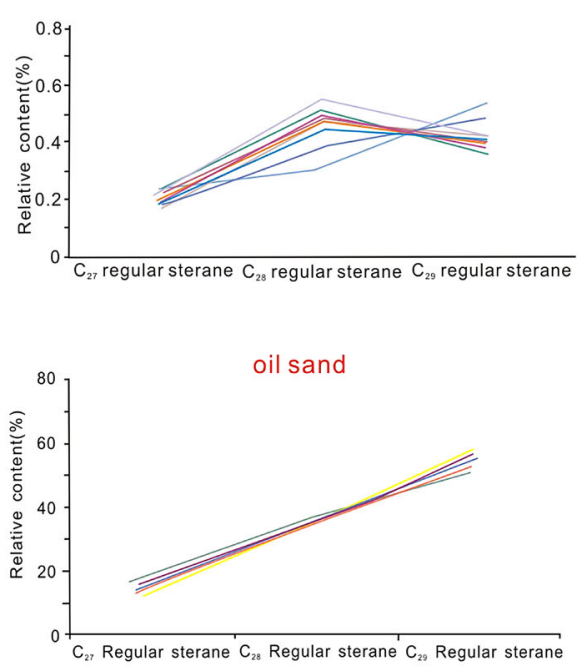

Source rocks in the interior of the

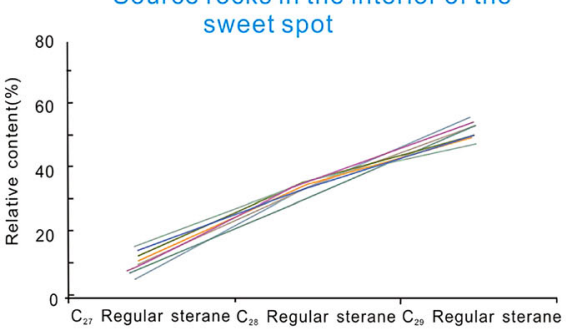

Source rocks under the sweet spot

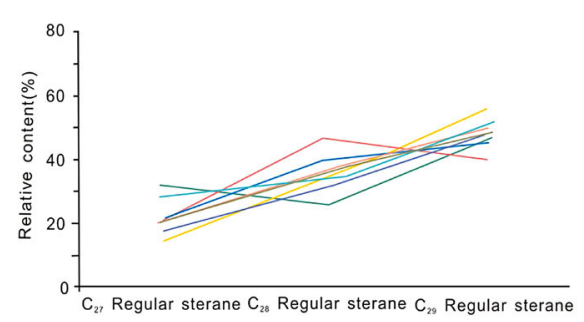

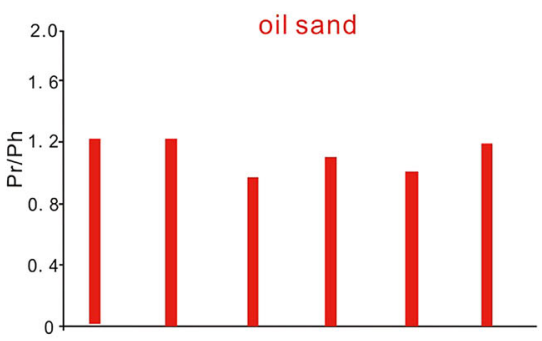

source rocks in the interior of

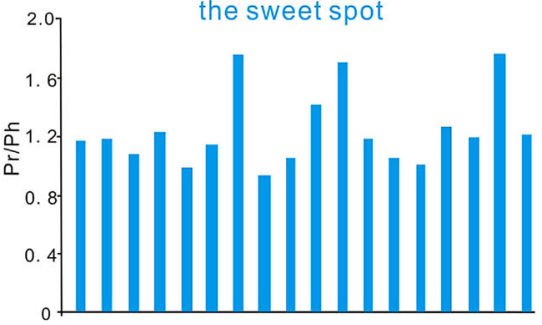

source rocks under the sweet spot
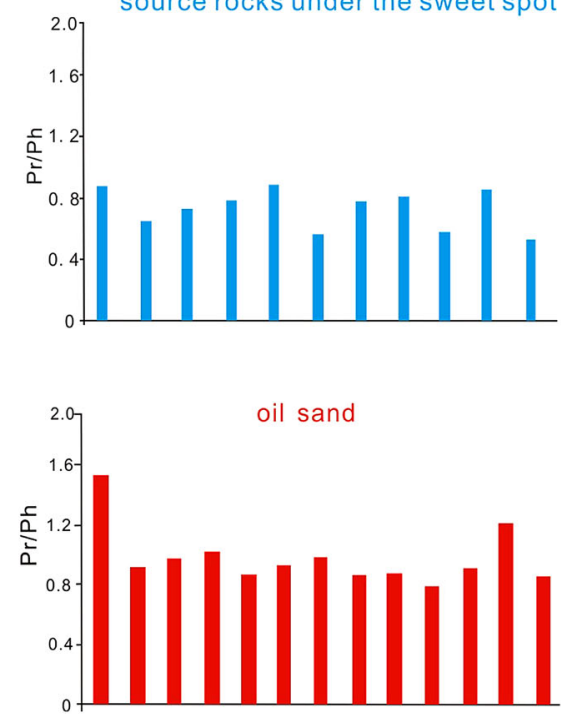

Source rocks in the interior of the

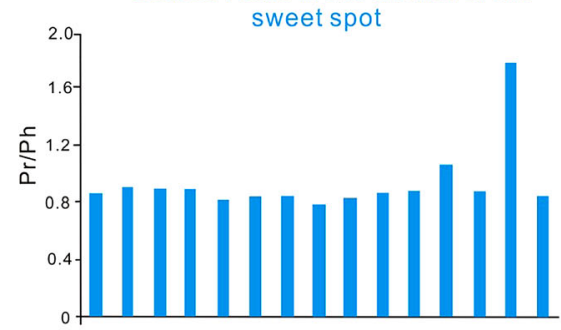

Source rocks under the sweet spot

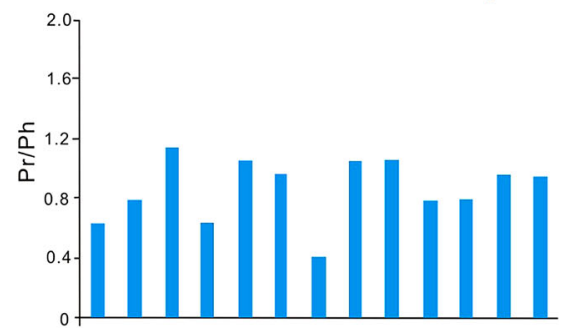



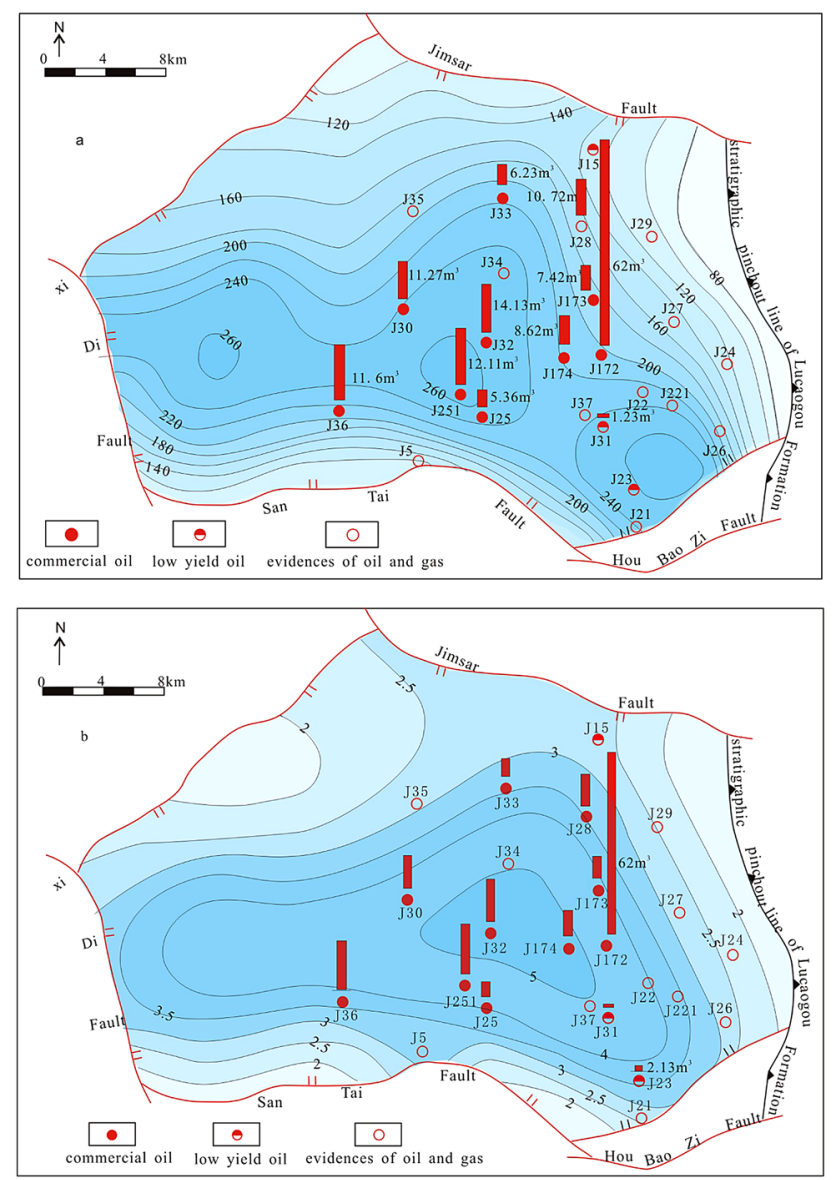

Fig. 8 Source rocks and tight oil distribution of LCG Formation in the Jimsar Sag, Junggar Basin: a source rocks thickness; b TOC of source rocks

\section{Conclusion}

1. The average total organic carbon content and hydrocarbon generating potential of LCG source rocks are $3.36 \%$ and $15.61 \mathrm{mg} / \mathrm{g}$, respectively, which have reached the standards for "good" hydrocarbon source rock. The LCG organic matter is dominated by type I and II kerogen and in the low maturity to mature evolution stage.

2. The analysis of the biomarker distribution indicates that the tight oil migration is dominated by primary or short-distance migration. In the upper sweet section, the tight oil and source rock both display high value of $\mathrm{Pr} / \mathrm{Ph}(>1)$, low $\mathrm{C}_{27}$ steranes, moderate $\mathrm{C}_{28}$ steranes, and high $\mathrm{C}_{29}$ steranes. And in the lower sweet spot, the tight oil and source rock also show the same characteristics.

(3) It is concluded that the LCG tight oil accumulation is controlled by source rocks, which is proved by that oil is mainly distributed in the region with thick source rocks and high abundance of organic matter.
Acknowledgements This work was supported by a grant from National Programs for Fundamental Research and Development of China (973 Program 2014CB239005), Natural Science Foundation of Shandong Province of China (ZR2016DL06), National Science and Technology Major Project of the Ministry of Science and Technology of China (2016ZX05006; 2016ZX05001), the Fundamental Research Funds for the Central Universities (17CX02006A). We also would like to thank Xinjiang Petroleum Administration Bureau of CNPC for providing the cored rock samples.

Open Access This article is distributed under the terms of the Creative Commons Attribution 4.0 International License (http:// creativecommons.org/licenses/by/4.0/), which permits unrestricted use, distribution, and reproduction in any medium, provided you give appropriate credit to the original author(s) and the source, provide a link to the Creative Commons license, and indicate if changes were made.

\section{References}

Arfaoui A, Montacer M, Kamoun F, Rigane A (2007) Comparative study between rock-eval pyrolysis and biomarkers parameters: a case study of Ypresian source rocks in central-northern Tunisia. Mar Pet Geol 24:566-578

Cao Z, Liu G, Zhan H et al (2016a) Geological control factors of micro oil distribution in tight reservoirs. Mar Pet Geol 77:1193-1205

Cao Z, Liu G, Zhan H et al (2016b) Pore structure characterization of Chang-7 tight sandstone using MICP combined with N2GA techniques and its geological control factors. Sci Rep 6:36919

Cao Z, Liu G, Xiang B et al (2017) Geochemical characteristics of crude oil from a tight oil reservoir in the Lucaogou Formation, Jimusar Sag, Junggar Basin. AAPG Bull 101:1-33

Ding X, Liu G, Zha M et al (2015) Characteristics and origin of lacustrine source rocks in the lower Cretaceous, Erlian Basin, northern China. Mar Pet Geol 66:935-955

Ding X, Liu G, Zha M et al (2016) Geochemical characterization and depositional environment of source rocks of small fault basin in Erlian Basin, northern China. Mar Pet Geol 69:231-240

Hill RJ, Zhang E, Katz BJ et al (2007) Modeling of gas generation from the Barnett shale, Fort Worth Basin, Texas. AAPG Bull 91:501-521

Jia C, Zou C, Li J et al (2012) Assessment criteria, main types, basic features and resource prospects of the tight oil in China. Acta Petrolei Sin 03:343-350 (in Chinese)

Jiang Y, Liu Y, Yang Z et al (2015) Characteristics and origin of tufftype tight oil in Jimusar Depression, Junggar Basin, NW China. Pet Explor Dev 42:741-749

Johnstone B (2007) Bakken black gold. Lead Poster 12:6

Kuang L, Tang Y, Lei D et al (2012) Formation conditions and exploration potential of tight oil in the Permian saline lacustrine dolomitic rock, Junggar Basin, NW China. Pet Explor Dev 39:657-667 (in Chinese)

Kuang L, Hu W, Wang X et al (2013a) Research of the tight oil reservoir in the Lucaogou Formation in Jimusar Sag: analysis of lithology and porosity characteristics. Geol J China Univ 19:529-535 (in Chinese)

Kuang L, Sun Z, Ou Y et al (2013b) Complication lithology logging identification of the Lucaogou tight oil reservoir in Jimusar depression. Well Logging Technol 37:638-642 (in Chinese)

Li H, Mao X, Hu G et al (2014) Junggar Basin Jimsar Sag Lucaogou formation tight oil reservoir characteristics and productivity prediction research. J Oil Gas Technol 36:40-44 (in Chinese) 
Miller B, Paneitz J, Mullen M (2008) The successful application of a compartmental completion technique used to isolate multiple hydraulic fracture treatments in horizontal Bakken Shale Wells in North Dakota. In: SPE Annual Technical Conference and Exhibition, Denver, Colorado

Mullen J (2010) Petrophysical characterization of the Eagle Ford Shale in South Texas. In: Canadian Unconventional Resources and International Petroleum Conference, Calgary, Alberta, Canada

National Key Basic Research and Development Program (973 Program) (2014) China terrestrial tight oil (shale oil) forming mechanism and enrichment rules basic research opening report, Beijing, 3-5 Apr 2014 (in Chinese)

Peng X, Wang L, Jiang L (2011) Analysis of sedimentary environment of the Permian Lucaogou Formation in southeastern margin of the Junggar Basin. J Xinjiang Univ (Nat Sci Ed) 28(4):395-400 (in Chinese)

Peters KE (1986) Guidelines for evaluating petroleum source rock using programmed pyrolysis. AAPG Bull 70:318-329

Si C, Chen N, Yu C et al (2013) Sedimentary characteristics of tight oil reservoir in Permian Lucaogou Formation, Jimsar Sag. Pet Geol Exp 35:528-533 (in Chinese)

USGS (2008) Assessment of undiscovered oil resources in the Devonian-Mississippian Bakken formation, Williston Basin
Province, Montana and North Dakota. USGS Fact Sheet, 2008-3021

Wang Z (2013) Research progress, existing problem and development trend of tight rock oil. Pet Geol Exp 35:587-595 (in Chinese)

Wang X, Sun L, Zhu R et al (2015) Application of charging effects in evaluating storage space of tight reservoirs: a case study from Permian Lucaogou Formation in Jimusar sag, Junggar Basin, NW China. Petr Explor Dev 42:516-524

Zhang J, Liu L, Huang Y et al (2003) Sedimentary characteristics of middle-upper Per Minin Jimusar Sag of Junggar Basin. Xinjiang Geol 21(4):412-414 (in Chinese)

Zhao X, Zhao Y, Deng Q et al (1994) Preliminary study of the sequence stratigraphy of upper Permian Lucaogou and Hongyanchi Formations on the southern edge of Jungar Basin. J Chengdu Univ Technol 1:112-120 (in Chinese)

Zou CN, Yang Z, Tao SZ (2013) Continuous hydrocarbon accumulation over a large area as a distinguishing characteristic of unconventional petroleum: the Ordos Basin, North-Central China. Earth-Sci Rev 126:358-369

Zou C, Tao S, Hou L et al (2014) Unconventional petroleum geology. Geological Publishing Press, Beijing, pp 137-167 (in Chinese) 